\title{
THE LAW OF DOMICILE: RE FOOTE ESTATE
}

\author{
GERALD B. ROBERTSON*
}

In the area of conflict of laws the concept of domicile has declined in importance over the last few decades, both as a connecting factor in choice of law ${ }^{1}$ and as a basis for jurisdiction, ${ }^{2}$ as well as a basis for recognition of foreign divorces. ${ }^{3}$ Consequently, it is quite rare these days to find a case devoted entirely to determining the question of a person's domicile. For that reason alone the recent decision of the Alberta Court of Queen's Bench in Re Foote Estate $^{4}$ is noteworthy. But what makes the case truly remarkable is the extent and depth of its scholarly review of the law of domicile. The Reasons for Judgment of Graesser J., spanning 546 paragraphs, contain what is unquestionably the most comprehensive and detailed judicial analysis of the law of domicile to be found in any Canadian case in recent times. ${ }^{5}$ Almost every aspect of domicile is canvassed with such depth and accuracy of analysis that the case will undoubtedly now be the starting reference point for practitioners and law students alike when grappling with the law of domicile.

In addition to its importance in providing such a comprehensive review of the law of domicile, there are a number of aspects of the decision that are especially noteworthy. After briefly setting out the facts and decision in Foote Estate, this case comment will then focus on four issues, in particular: (1) the determination of domicile by the lex fori; (2) the standard of proof in establishing a change in domicile; (3) judicial discretion to refuse to apply the revival of the domicile of origin; and (4) the abandonment of a domicile of choice.

\section{FACTS AND DECISION}

The case involved the estate of the late Eldon Foote, who died on 14 May 2004. The specific question for the Court was where Mr. Foote was domiciled when he died, ${ }^{6}$ because

Q.C., LL.B., LL.M., Professor of Law, University of Alberta.

This has occurred both as a result of changes in the common law choice of law rules, and (more especially) as a result of legislation. With respect to the former, see e.g. the Federal Court of Appeal's acceptance (and extension) of the intended matrimonial home theory as an alternative to domicile to govern the essential validity of marriage in Canada (Minister of Employment and Immigration) $v$. Narwal, [1990] 2 F.C. 385 (C.A.). With respect to the latter, see e.g. Uniform Wills Act (revised 1966), s. 40(1) (Uniform Law Conference of Canada, "Conflict of Laws Governing Wills" in Uniform Law Conference of Canada, Proceedings of the Forty-Eighth Annual Meeting, Minaki, Ontario, 1966 131, online: Uniform Law Conference of Canada <http://www.ulcc.ca/en/poam2/48th\%20Annual\%20 Meeting.pdf>); Wills Act, R.S.A. 2000, c. W-12, s. 40. See also the abolition of the common law rules of domicile and the equation of domicile with habitual residence in The Domicile and Habitual Residence Act, R.S.M. 1987, c. D-96 [Domicile Act].

2 For example, jurisdiction in divorce cases prior to 1986 required one spouse to be domiciled in Canada. With the enactment of the Divorce Act, R.S.C. 1985 (2d Supp.), c. 3, s. 3(1), divorce jurisdiction is no longer based on domicile but instead depends entirely on the concept of ordinary residence. Likewise, jurisdiction in matrimonial property cases (and, in many provinces, child custody cases) is now based on the concept of habitual residence: see e.g. Matrimonial Property Act, R.S.A. 2000, c. M-8, s. 3; Children's Law Reform Act, R.S.O. 1990, c. C-12, s. 22(1).

The statutory ground for recognition is now based on ordinary residence: see Divorce Act, ibid., s. 22(1). The common law grounds for recognition (which are preserved by s. 22(3) of the Divorce Act) have been expanded beyond domicile and now include the concept of real and substantial connection: see Indyka v. Indyka, [1969] 1 A.C. 33 (H.L.).

Re Foote Estate, 2009 ABQB 654, 475 A.R. 273 [Foote Estate].

For an English equivalent, see Mark v. Mark, [2005] UKHL 42, [2006] 1 A.C. 98.

An earlier decision dealt with jurisdiction: Re Foote Estate, 2007 ABQB 654, 431 A.R. 338. 
this in turn would determine whose law would govern succession to his moveable estate, as well as family relief claims against the estate.

Born in Hanna, Alberta in 1924, with a domicile of origin in Alberta, and having lived the first 43 years of his life in Alberta, Foote then started a business in Australia and travelled extensively in Australia, Japan, and Europe. In the 1970s he purchased property and built a home on Norfolk Island (a tropical island approximately 1,000 miles east of Sydney, Australia) and he and his then wife acquired permanent residency status there in 1977 . He married again in 1984, and his new wife was granted permanent residency status on Norfolk Island in 1996. In 1999, Foote and his wife purchased a condominium property in Victoria, British Columbia, which was completed in 2001, and they spent each of the summers of 2001, 2002, and 2003 there. Around this time they also made plans to sell their home on Norfolk Island, although it was never listed or advertised for sale. Sadly, Foote's health then began to fail. In April 2004 he was diagnosed with cancer and travelled to Edmonton to receive treatment at the Cross Cancer Clinic, where he died the following month. ${ }^{7}$

Justice Graesser ultimately held that Foote died domiciled in Norfolk Island. He found that Foote had acquired a domicile of choice there by at least 1972, and had not abandoned it prior to his death. In particular, despite having established a second home in British Columbia in 2001, he had not acquired a domicile of choice there because he lacked the necessary intention to settle in British Columbia indefinitely. In addition, because he had not abandoned his Norfolk Island domicile of choice, the doctrine of reversion of his domicile of origin (Alberta) did not apply.

\section{DETERMinATION OF DOMICILE BY THE LEX FORI}

It is well-established that a court should apply its own law (the law of the forum - the lex fori) in determining domicile. ${ }^{8}$ For example, in deciding whether a child is no longer a minor and therefore has the capacity to abandon the domicile of dependence on its parent and acquire its own domicile of choice, the court will apply the age of majority under the lex fori. $^{9}$

In his Reasons for Judgment in Foote Estate, Graesser J. applied the lex fori principle, and in so doing he expressly declined to follow the Alberta decision in Davies v. Davies. ${ }^{10}$ In Davies, a petition for the nullity of a voidable marriage was commenced by a wife who was living permanently in Alberta but whose husband was domiciled in Ontario. The issue for the Court was jurisdiction: was the petitioner domiciled in Alberta? Traditional common law principles of domicile - in particular, the married woman's domicile of dependence on her husband - would have dictated that the wife was domiciled in Ontario and not in Alberta. However, McDonald J. held that because legislation in Ontario had abolished the married

Foote Estate, supra note 4 at paras. 117-74.

Janet Walker \& Jean-Gabriel Castel, Canadian Conflict of Laws, 6th ed. (Toronto: LexisNexis, 2005) vol. 1 at para. 4.3. See also Sir Lawrence Collins, ed., Dicey, Morris \& Collins on The Conflict of Laws, 14th ed. (London: Sweet \& Maxwell, 2006) vol. 1 at 129.

$9 \quad$ See e.g. Harrison v. Harrison, [1953] 1 W.L.R. 865 (H.C., Probate, Divorce \& Admiralty Division). (1985), 64 A.R. 73 (Q.B.) [Davies]. 
woman's domicile of dependence, ${ }^{11}$ the petitioner should be regarded as having a domicile of choice in Alberta rather than a domicile of dependence in Ontario.

Although the leading academic authority in Canada on the conflict of laws endorses the decision in Davies ${ }^{12}$ and cites it for the proposition that capacity to acquire a new domicile is governed by the law of the existing domicile, Graesser J. declined to follow the Davies decision and held that it is not good law on the basis that it is inconsistent with the fundamental principle that domicile is determined according to the lex fori. It is submitted that Graesser J. was correct in doing so.

\section{Standard of Proof in Establishing A Change in Domicile}

The decision in Foote Estate is also important in clarifying the standard of proof that applies in establishing a change of domicile. Considerable uncertainly has surrounded this issue, including whether the standard of proof is the normal civil one (balance of probabilities) or perhaps some higher standard, particularly in cases of a change from domicile of origin to domicile of choice. ${ }^{13}$ In particular, the leading academic authority in Canada states that

\footnotetext{
[t]he task of proving a change of domicile is particularly onerous when the domicile alleged to be displaced is one of origin as opposed to one of choice. Similarly, a high degree of proof may be required to establish a change in domicile where the two legal units are markedly dissimilar in language, climate, or ethnic, cultural or religious background. Thus, in Canada a lesser degree of proof is required to establish a change of domicile from one province to another than when the change is to or from another country. ${ }^{14}$
}

In light of the recent decision of the Supreme Court of Canada in F.H. v. McDougall, ${ }^{15}$ Graesser J. held that the civil onus of proof on a balance of probabilities is the correct one to apply in all domicile cases and he expressly rejected the principle that a higher standard of proof applies to the displacement of a domicile of origin. He also rejected the concept that the nature and character of the legal unit that is alleged to be the domicile of choice is relevant to the standard of proof. ${ }^{16}$ In his words, "whether a change of domicile involves a relocation within or between countries is irrelevant, as are language, climate, ethnic, cultural or religious characteristics of the different possible domiciles."17

The same is now true in Alberta: see Family Law Act, S.A. 2003, c. F-4.5, s. 104.

Walker \& Castel, supra note 8 at para. 4.3. Referring to the decision in Davies, the authors state that "[c]apacity to acquire a domicile of choice in a new legal unit is determined by the courts of that unit in accordance with the law of the individual's domicile at that time."

See Walker \& Castel, ibid. at para. 4.10. See also Collins, supra note 8 at 128-29.

Walker \& Castel, ibid. [footnotes omitted].

2008 SCC 53, [2008] 3 S.C.R. 41.

Foote Estate, supra note 4 at paras. 71-74.

Ibid. at para. 544. 


\section{REVIVAL OF THE DOMICILE OF ORIGIN}

At common law, ${ }^{18}$ if a domicile of choice is abandoned and a new domicile of choice is not acquired, the person's domicile of origin revives. ${ }^{19}$ This is in keeping with the fundamental principle that a person can never be without a domicile. ${ }^{20}$ The revival of the domicile of origin was relevant in Foote Estate because, if Foote had been found to have abandoned his domicile of choice in Norfolk Island without acquiring a new domicile of choice (in British Columbia), his domicile of origin would have revived and he would have died domiciled in Alberta despite not having lived there for the last 37 years of his life.

As we have seen, Graesser J. held that Foote had not abandoned his domicile of choice in Norfolk Island, and so his domicile of origin did not revive. However, Graesser J. also indicated that he would have declined to apply the doctrine of revival of the domicile of origin if he had found that Foote had abandoned his domicile of choice without acquiring a new one. ${ }^{21}$ Justice Graesser held that a court has a residual discretion to depart from the doctrine of revival of the domicile of origin "to avoid an absurd result.",22 He defined "an absurd result" as including a situation where the revived domicile of origin "had absolutely no relevance to a person's life, home, and activities," ${ }^{23}$ which was certainly true of Foote's connection to Alberta at the time of his death.

The common law doctrine of revival of the domicile of origin has been the subject of considerable criticism, ${ }^{24}$ and hence the idea that a court has a residual discretion to depart from it is an appealing one. However, the existence of this discretion rests on a very tenuous basis. The only case cited in Foote Estate in support of it is Re Montizambert Estate, ${ }^{25}$ a 1973 decision of the Ontario High Court; in particular, the following passage from the judgment:

Writers on the problem of conflicts of law have noted that the doctrine of revival of domicile of origin can produce anomalous results, and this would be a case in which such an anomalous result would obtain....

[T] here is no evidence to suggest that the deceased had any real connection with Quebec after 1882, some

82 years before her death. To suggest that her personal law should be the law of a jurisdiction which the deceased left 82 years before her death is to defy common sense. While the law of domicile is sometimes, by its nature, artificial and confusing, it ought not to be totally divorced from reality. ${ }^{26}$

Some jurisdictions (such as Australia and New Zealand) have abolished the common law doctrine of revival of the domicile of origin. In Canada it has been abolished in Manitoba and Quebec: see Domicile Act, supra note 1, s. 3; Civil Code of Québec, Arts. 75-83 C.C.Q. Abolition is also recommended in the Uniform Law Conference of Canada, "Draft Model Act to Reform and Codify the Law of Domicile” in Uniform Law Conference of Canada, Proceedings of the Forty-Third Annual Meeting, Regina, Saskatchewan, 1961 139, online: Uniform Law Conference of Canada <http://www.ulcc.ca/en/ poam2/43rd\%20Annual\%20Meeting.pdf>. Udny v. Udny (1869), [1866-1869] L.R. 1 Sc. \& Div. 441 (H.L.); Walker \& Castel, supra note 8 at paras. 4.5, 4.8; Collins, supra note 8 at 151-53.

Walker \& Castel, ibid. at para. 4.4; Collins, ibid. at 126.

Foote Estate, supra note 4 at para. 515.

Ibid. at paras. 97, 544.

Ibid. at para. 97.

See e.g. Walker \& Castel, supra note 8 at para. 4.16; Collins, supra note 8 at 152; C.M.V. Clarkson \& Jonathan Hill, The Conflict of Laws, 3d ed. (Oxford: Oxford University Press, 2006) at 25-27; U.K., The Law Commission, Private International Law: The Law of Domicile (Report No. 168) (London: Her Majesty's Stationery Office, 1987) at para. 5.25. The common law rule has been abolished in some jurisdictions: see supra note 18.

$25 \quad$ [1973] O.J. No. 1035 (S.C.) (QL) [Montizambert Estate].

Ibid. at para. 32. 
There are a number of problems with Graesser J.'s reliance on Montizambert Estate in support of the existence of a residual discretion to depart from the doctrine of revival of the domicile of origin. First, the Court in Montizambert Estate did not in fact purport to exercise a discretion to depart from the revival doctrine. As is clear from the paragraph immediately following the one quoted above, ${ }^{27}$ the Court merely concluded that the problems associated with the revival doctrine reinforced its decision that the deceased had acquired a domicile of choice in England prior to her death, and hence her domicile of origin in Quebec did not revive. The Court did not reject the revival doctrine; it merely held that it did not apply because the deceased had acquired a domicile of choice prior to her death.

Second, none of the leading academic textbooks on the conflict of laws, both in Canada ${ }^{28}$ and in England, ${ }^{29}$ make any acknowledgement of a residual discretion to depart from the doctrine of revival of the domicile of origin, which is a curious omission if such a discretion exists.

Third, Graesser J.'s application of the discretion is problematic on the facts of the case. He interpreted Montizambert Estate as supporting the proposition that where the revival of the domicile of origin would produce an absurd result, the court has a residual discretion "to instead conclude that a person has retained their last domicile of choice." ${ }^{30}$ And yet, applying this discretion, Graesser J. held that Foote's domicile at death would have been British Columbia, ${ }^{31}$ which is inconsistent with his finding that Foote's last domicile of choice was Norfolk Island.

Perhaps the most important problem with the concept of a residual judicial discretion to depart from the doctrine of revival of the domicile of origin is not simply the source of the discretion, but rather its scope. Why should it be limited to the revival of the domicile of origin? Many aspects of the law of domicile have the potential to produce absurd results, in the sense of concluding that a person is domiciled in a place with which they have little or no connection. The common law doctrine of a married woman's domicile of dependence on her husband is a prime example. ${ }^{32}$ It is by no means the only one. The concept of a judicial discretion to displace common law domicile rules in order to avoid "an absurd result" has the potential to create considerable uncertainty. It is far better, it is submitted, to avoid the absurdity by means of legislative reform of the law of domicile along the lines recommended by the Uniform Law Conference of Canada. ${ }^{33}$

"In my opinion, therefore, the deceased acquired a new domicile of choice in England and never lost it. In the result, therefore, I conclude that the deceased died domiciled in England": ibid. at para. 33.

Walker \& Castel, supra note 8.

Collins, supra note 8.

Foote Estate, supra note 4 at para. 97 [emphasis added].

Ibid. at para. 515. Possibly, however, this may have been an unintentional slip and Graesser J. may have intended to refer to Norfolk Island rather than to British Columbia.

32 Though now abolished by legislation in Alberta — see supra note 11 - the legislation is not retroactive, and hence the common law rule will still apply in determining a wife's domicile prior to the proclamation of the legislation.

Supra note 18. 


\section{Abandonment of A Domicile of Choice}

In concluding that Foote had not abandoned his domicile of choice on Norfolk Island, Graesser J. endorsed the principle enunciated in the English case of Inland Revenue Commissioners $v$. Duchess of Portland, ${ }^{34}$ namely, that in order to abandon a domicile of choice one must abandon both components — intention and residence — and that abandonment of the latter involves leaving the jurisdiction with the intention of not returning to live there; that is, leaving the jurisdiction permanently. ${ }^{35}$ In other words, even if Foote had given up his intention to reside on Norfolk Island indefinitely, he had not abandoned his intention to reside there for the time being and, therefore, he had not abandoned his residence (and hence his domicile of choice) on Norfolk Island.

This acceptance of the Duchess of Portland principle is significant because it highlights an important difference between the acquisition and the abandonment of a domicile of choice. With respect to the former (acquisition), the elements of intention and residence are entirely separate. ${ }^{36}$ In particular, "residence” means mere physical presence, and hence a person will acquire a domicile of choice in a jurisdiction as soon as they set foot there assuming that they have the necessary intention to reside there indefinitely. ${ }^{37}$ Abandonment, however, is different. The Duchess of Portland case, as affirmed by Foote Estate, shows that to abandon a domicile of choice the core elements of intention and residence are not discrete. In particular, even if one abandons the intention to reside in the jurisdiction indefinitely and then physically leaves the jurisdiction, an intention to return and to resume residence in the jurisdiction (albeit not indefinitely) means that residence has not been abandoned, and hence neither has the domicile of choice. In other words, whereas the two elements of intention and residence are quite distinct with respect to the acquisition of a domicile of choice, the two are interrelated in the context of the abandonment of a domicile of choice.

\section{ConCLUSION}

Because of its declining importance, domicile is now rarely a subject of detailed judicial analysis. The decision of Graesser J. in Foote Estate is a noteworthy exception, and is quite remarkable for the extent and depth of its analysis of the current law of domicile. 